\title{
HEALTH CARE EFFECT OF SPORTS ON IMPROVING PHYSICAL FUNCTION
}

EFEITO DE ATENÇÃO À SAÚDE DO ESPORTE NA MELHORIA DA FUNÇÃO FÍSICA

EFECTO DEATENCIÓN A LA SALUD DEL DEPORTEEN LA MEJORÍA DE LA FUNCIÓN FÍSICA

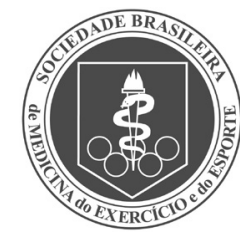

Original Article

ARTIGo ORIGINAL

Artículo Original

\section{Yi Yang ${ }^{1}$ (iD)}

(Physical Education Professional)

Huiquan $\mathrm{He}^{1}$ (D)

(Physical Education Professional)

1. Cangzhou Medical College,

Cangzhou, Hebei, China.

\section{Correspondence:}

Huiquan $\mathrm{He}$

Cangzhou, Hebei, 061001. China.

yh202235@163.com

\begin{abstract}
Introduction: One of the basic tasks of physical education in colleges and universities is to guide students to exercise and strengthen their physical fitness. Therefore, we need to study the physical function status of college students and the law of change in the learning process. Objective: To conduct physical training for college students and study the impact of exercise on physical function. Methods: Female college students are randomly divided into three groups with different training programs. The training cycle lasts 12 weeks. Results: There were statistical differences in the physical functions and qualities of the three groups of students after different training programs. Aerobic and strength training has obvious effects on improving students' skills. Conclusion: The combination of aerobic exercise and strength training enhances the physical function of female students. Level of evidence ll; Therapeutic studies - investigation of treatment results.
\end{abstract}

Keywords: Students; Aerobic Exercises; Exercise; Physical Fitness.

\section{RESUMO}

Introdução: Uma das tarefas básicas da educação física em escolas e universidades éorientar os alunos para que façam exercícios e fortaleçam sua aptidão física. Portanto, precisamos estudar o status da função física de estudantes universitários e a lei da mudança no processo de aprendizado. Objetivo: Conduzir treinamentos físicos para alunos universitários e estudar o impacto da atividade na função física. Métodos: Universitárias (sexo feminino) foram aleatoriamente separadas em três grupos, com diferentes programas de treinamento. O ciclo de treinamento durou 12 semanas. Resultados: Houve diferenças estatísticas na função e qualidade físicas dos três grupos de estudantes depois de programas de treinamento diferentes. Treinos aeróbicos e de força tem efeitos evidentes na melhoria da habilidade das estudantes. Conclusão: O exercício aeróbico combinado com treino de força melhora a função física de estudantes do sexo feminino. Nível de evidência Il; Estudos terapêuticos - investigação de resultados de tratamento.

Descritores: Estudantes; Exercício Aeróbico; Exercício Físico; Aptidão Física.

\section{RESUMEN}

Introducción: Una de las tareas básicas de la educación física en escuelas y universidades es orientar a los alumnos para que hagan ejercicios y fortalezcan su aptitud física. Por lo tanto, necesitamos estudiar el status de la función física de estudiantes universitarios y la ley del cambio en el proceso de aprendizaje. Objetivo: Conducir entrenamientos físicos para alumnos universitarios y estudiar el impacto de la actividad en la función física. Métodos: Universitarias (sexo femenino) fueron aleatoriamente separadas en tres grupos, con diferentes programas de entrenamiento. El ciclo de entrenamiento duró 12 semanas. Resultados: Hubo diferencias estadísticas en la función y calidad físicas de los tres grupos de estudiantes después de programas deentrenamiento diferentes. Entrenamientos aeróbicos y de fuerza tienen efectos evidentes en la mejoría de la habilidad de las estudiantes. Conclusión: El ejercicio aeróbico combinado con entrenamiento de fuerza mejora la función física de estudiantes del sexo femenino. Nivel de evidencia Il; Estudios terapéuticos - investigación de resultados de tratamiento.

Descriptores: Estudiantes; Ejercicio Aeróbico; Ejercicio Físico; Aptitud Física.

\section{INTRODUCTION}

Cross-century college students shoulder the important task of rejuvenating the country through science and education. This requires them to have a healthy body. Female college students with the appropriate weight, less body fat, and better bone and muscle development have better body systems. ${ }^{1}$ There is a certain amount of research on the physique of low-weight female college students. However, there are few studies on how to improve the physical fitness of low-weight female college students. Therefore, this article intends to use a combination of aerobic exercises and strength training for 12 weeks to observe the changes in physical fitness of low-weight female college students before and after exercise. At the same time, compare the indicators of three groups of low-weight female college students. In this way, methods and measures to improve and improve the physique of low-weight female college students are discussed. This can provide a theoretical basis and reference for female college students' physical education and fitness in China. ${ }^{2}$ At the same time, the article can also provide some methods and measures for improving the physical fitness of our nationals and students. 


\section{METHOD}

\section{Research objects and groups}

The research object is a female college student of a certain university. 60 low-weight female college students with $\mathrm{BMI} \leq 20$ were calculated through height and weight measurement. We randomly group them. ${ }^{3}$ Among them, 30 were in the training group, 15 were in the training control group, and 15 were in the untrained control group. There were no significant differences in the indicators of the three groups of research subjects. Requirements for the training and control groups: (1) All students have not undergone systematic physical exercise. (2) All students have no visceral diseases, metabolic diseases, and exercise contraindications. (3) Volunteer to participate in 12 weeks of exercise. The untrained control group had a normal study and life. A small bag of milk $(243 \mathrm{ml})$ and an apple were added to the original diet principle in terms of nutrition. The training program of the research object is shown in Table 1. The training method of the training group. Table 2 Exercise methods of the training control group.

Table 1. Exercise methods of the training group.

\begin{tabular}{|c|c|c|}
\hline Purpose & $\begin{array}{c}\text { Develop cardiopulmonary } \\
\text { function }\end{array}$ & Gain weight \\
\hline $\begin{array}{l}\text { Exercise } \\
\text { mode }\end{array}$ & Aerobics, skipping rope & Strength Training \\
\hline $\begin{array}{l}\text { Exercise } \\
\text { intensity }\end{array}$ & $\begin{array}{c}1 \sim 6 \text { weeks: target heart rate }= \\
(\text { HRmax-HRrest }) \times(40 \%-60 \%)+ \\
\text { heart rate at rest } 7 \sim 12 \text { weeks: } \\
\text { target heart rate }=(\text { HRmax-HRrest }) \\
\times(60 \%-80 \%)+\text { heart rate at rest }\end{array}$ & $\begin{array}{l}1 \sim 6 \text { weeks: } 10 \sim 15 \text { times } \\
\times 3 \text { groups, } 65 \% \sim 75 \% \text { of } \\
\text { maximum weight; } 7 \sim 12 \text { weeks: } \\
8 \sim 10 \text { times } \times 3 \text { groups, } 75 \% \\
\sim 80 \% \text { of maximum weight }\end{array}$ \\
\hline Frequency & 35.4 & 26.4 \\
\hline Time & $30 \sim 40$ minutes & $30 \sim 40$ minutes \\
\hline Site & Gym & Gym \\
\hline
\end{tabular}

Table 2. Exercise methods of the training control group.

\begin{tabular}{c|c}
\hline Purpose & Gain weight \\
\hline Exercise mode & Strength Training \\
\hline Exercise intensity & $\begin{array}{c}\text { 1 6 weeks: 10 15 times } \times 3 \text { groups, 65\% 75\% } \\
\text { of maximum weight; } 7 \sim 12 \text { weeks: } 8 \text { 10 times } \times \\
3 \text { groups, 75\% 80\% of maximum weight }\end{array}$ \\
\hline Frequency & 2 3 times a week \\
\hline Time & 30 40 minutes \\
\hline Site & Gym \\
\hline
\end{tabular}

\section{Research indicators}

The physical function test covers indicators such as pulse, blood pressure, vital capacity, step test, etc.

\section{Research methods}

The literature data method collects and organizes relevant literature on the physical exercise of low-weight female college students at home and abroad through books and materials. ${ }^{4}$ The student's physique test method adopts the Huaxia Huaihai brand wireless intelligent tester produced in Beijing.

\section{Assessment of Sports Skills Ability}

Construct a statistical information analysis model for the evaluation of sports skills and abilities. According to the mining results of the evaluation information of sports skills and ability, the characteristics of sports skills and ability are reconstructed..$^{5}$ Constructing a regression analysis model for the assessment of sports skills and abilities is expressed as:

$$
x_{i}=\left\{\begin{array}{l}
0, M-\sum_{j=1}^{[n / 2]} \omega_{j}-\sum_{j=[n / 2]+1}^{i} \omega_{j}-\sum_{j=i+1}^{k} \omega_{j}<0, i \leq k \\
f_{i}(M, n, \omega, c, r)=\min \{f(M, n, \omega, c, r)\} \\
1, M-\sum_{j=1}^{[n / 2]} \omega_{j}-\sum_{j=[n / 2]+1}^{i} \omega_{j}-\sum_{j=i+1}^{k} \omega_{j}>0
\end{array}\right.
$$


and the measurement method is expressed in times per minute. ${ }^{7}$ Heart rate is one of the most commonly used physiological indicators in the evaluation of cardiac function. Changes in heart rate can judge the effect of exercise on heart function. The intravenous injection rate of the training group was lower than that of the training control group and the untrained control group. This shows that the training group combined aerobic exercise and strength training after 12 weeks of exercise is better than the single strength training of the training control group. This is more obvious than low-weight female college students who did not exercise in the control group. In recent years, some domestic scholars have used non-invasive quantitative analysis methods to detect changes in cardiac hemodynamics and have obtained relatively consistent results. ${ }^{8}$ Compared with ordinary people, athletes have a low pulse rate, a large heart output per stroke, a large heart output per distraction, a large heartbeat index, and a large effective left ventricular pump power when athletes are at rest. After the load, the changes of the above indicators are better than those of ordinary people. This shows that the heart function of athletes is better than that of ordinary people. Many scholars have used different methods to study training effects on the heart and have reached similar conclusions. After long-term systematic sports training, the athlete's heart shape structure and function can have adaptive changes. This good response is very important for improving the heart pumping capacity and increasing the body's oxygen metabolism capacity.

\section{The effect of physical exercise on blood pressure}

Blood pressure refers to the lateral pressure on the sidewall of the blood vessel when blood flows in the blood vessel. Blood pressure is an important content for vital signs and the internal environment to remain stable. Too high or too low blood pressure is bad for health. It is a complete result of the interaction of many factors, namely, hemodynamic variables. The imbalance of the relationship between these dynamic variables can lead to changes in blood pressure. In turn, blood pressure will increase or decrease. The systolic blood pressure reflects the speed, intensity, aortic elasticity, cardiac output, and arterial volume of the heart contraction. The diastolic blood pressure mainly reflects the resistance encountered when the blood flows out. The arterial system is closely related to blood pressure and the capillary and venous systems.

The object in this study is constitutional hypotension. The hazard of hypotension is the insufficient blood supply to the various organs of the human body, especially the ischemic damage to the brain tissue is extremely prominent. Patients often experience dizziness, headaches, dark eyes, forgetfulness, slow thinking, and are prone to ischemic stroke, angina pectoris, and myocardial infarction. At present, there is no particularly effective treatment for hypotension. Physical exercise helps enhance the function of the cardiovascular system, helps it improve the process of excitement and inhibition of the cerebral cortex, and is conducive to the rise of blood pressure. Exercise plays a two-way role in improving blood pressure. The systolic blood pressure of the training group was higher than that of the training control group and the untrained control group. This shows that the aerobic exercises of aerobics and rope skipping in this study have a certain effect on the blood pressure of low-weight female college students.

\section{The effect of physical exercise on vital capacity}

The cardiopulmonary function is the most important factor in physical health. Represents the ability of the human cardiovascular system and respiratory system to ingest, transport, absorb and use oxygen for metabolism to generate energy. A good cardiopulmonary function is to engage in daily activities with sufficient energy and ability. It can help prevent certain chronic diseases and promote the foundation of physical and mental health. At the same time, a cardiopulmonary function is an important factor affecting physical fitness. In addition to genetic factors, the human cardiopulmonary function is mainly affected by acquired activities and regular exercise. Regular physical exercise can effectively enhance the physiological functions and adaptability of the body's various organ systems.

Vital capacity is an important indicator that reflects the athletic ability of students. The vital capacity of the training group was higher than that of the training control group and the untrained control group. This shows that the training group combined aerobic exercise and strength training after 12 weeks of exercise is better than the single strength training of the training control group. This may be that aerobic exercises have a certain effect on improving the physical function of low-weight female college students. This method helps to improve the metabolism of the whole body.

\section{CONCLUSION}

Aerobic exercise has an immeasurable effect on health. Only persevering in aerobic fitness exercise can be more conducive to improving and enhancing the function of the respiratory system and cardiovascular systems. This method can improve the regulating function of the central nervous system to enhance the physique of female college students. Aerobic exercise can promote the coordinated growth and development of female college students and maintain emotional energy. In turn, it can promote their physical and mental health and improve their learning effects. In short, aerobic exercise has a certain effect on improving health. Strength training can maintain or increase lean body mass. The combination of aerobic exercise and strength exercise through direct and indirect energy consumption is the preferred exercise for weight gain and maintenance of lean body mass or increased lean body mass. The combination of aerobic exercise and strength training has a certain effect on enhancing the physical function of low-weight female college students. Low-weight people are more suitable for this type of exercise that combines aerobic exercises and strength training.

All authors declare no potential conflict of interest related to this article

AUTHORS' CONTRIBUTIONS: Each author made significant individual contributions to this manuscript. Yi Yang: writing and performing surgeries; Huiquan He: data analysis and performing surgeries, article review, and intellectual concept of the article.

\section{REFERENCES}

1. Huo Y, Huang W. Extreme rainfall response based on SAR imaging and home sports training effect. Arabian Journal of Geosciences. 2021;14(15):1-12.

2. Zhang J. Biological analysis of trunk support strength training in sports training. Network Modeling Analysis in Health Informatics and Bioinformatics. 2021;10(1):1-12.

3. Liang H. Evaluation of fitness state of sports training based on self-organizing neural network. Neural Computing and Applications. 2021;33(9):3953-65.

4. Li H. Influence of Sports Training on Function of Human Body in Different Ecological Environment. Ekoloji. 2019;28(108):2003-8.
5. Liang $\mathrm{L}$, Beina $\mathrm{H}$. Simulation of rainfall process in mountainous regions and sports athletes' fatique recovery based on convolutional neural network. Arabian Journal of Geosciences. 2021;14(11):1-15.

6. Alhanif MAHN, Rejeki PS, Herawati L. Student's Participation In Extracuricular School Sports Has Positive Impact On Executive Functions. STRADA Jurnal IImiah Kesehatan. 2020;9(2):1047-55.

7. Looi QH, Eng SP, Liau LL, Tor YS, Bajuri MY, Ng MH et al. Mesenchymal stem cell therapy for sports injuries-From research to clinical practice. Sains Malaysiana. 2020;49(4):825-38.

8. Ziyu L, Qingyao S. Rock stress and deformation characteristics based on SVM and sports high-intensity interval training. Arabian Journal of Geosciences. 2021;14(17):1-12 